A N N A L ES

UNIVERSITATIS MARIAE CURIE-SKŁODOWSKA

LUBLIN - POLONIA

VOL. LXVI, 1

SECTIO G

2019

Uniwersytet Marii Curie-Skłodowskiej w Lublinie

WOJCIECH DZIEDZIAK

wojciech.dziedziak@poczta.umcs.lublin.pl

ORCID: 0000-0002-7335-8471

\title{
Godność człowieka jako podstawa sprawiedliwości
}

Human Dignity as the Fundamental of Justice

I.

Sprawiedliwość należy do fundamentalnych wartości uniwersalnych i ogólnoludzkich. Zdaniem wielu jest ona najważniejszą wartością prawa. Jednakże, pomimo ogromnej wielości prac poświęconych sprawiedliwości, jej rozumienie nadal jest rzeczą dyskusyjną w zależności od zajmowanego stanowiska filozoficznego. Trzeba powiedzieć mocniej - wciąż jest to kategoria bardzo sporna. W literaturze napotykamy różne koncepcje, ujęcia i teorie sprawiedliwości.

Współcześnie kategoria sprawiedliwości została na ogół zsubiektywizowana, bywa zatracany jej moralny czy etyczny charakter, nadal modne i dominujące są narracje właściwe zarówno dla myśli liberalnej, utylitarnej, jak i neomarksistowskiej. Przyjmuje się, że podstawą sprawiedliwości jest konwencja. Kategoria ta znajduje oparcie właśnie w jakiejś konwencji społeczno-pragmatycznej, konstruktach umownych (hipotetyczna umowa) ${ }^{1}$ czy też w przeżyciach, uczuciach, emocjach (w literaturze naukowej pisze się o ,silnym zabarwieniu emocjonalnym

1 Szerzej: J. Rawls, Teoria sprawiedliwości, Warszawa 1994. Warto podkreślić, że Ronald Dworkin (Biorac prawa poważnie, Warszawa 1998, s. 278) w tym kontekście stwierdza: „Rawls nie przypuszcza, iż jakakolwiek grupa kiedykolwiek zawarła umowę społeczną w opisany przez niego sposób. Twierdzi tylko, że jeśli grupa ludzi racjonalnych znalazłaby się w warunkach sytuacji pierwotnej, przystaliby oni na umowę zakładającą przestrzeganie dwóch wspomnianych zasad. Jego umowa jest hipotetyczna, a hipotetyczne umowy nie są w stanie dostarczyć niezależnego argumentu przemawiającego za tym, iż sprawiedliwe jest przestrzeganie ich warunków. Hipotetyczna umowa nie jest po prostu słabą postacią umowy rzeczywistej; to nie jest w ogóle żadna umowa". 
tego pojęcia") $)^{2}$. Często twierdzi się wprost, że podstawy sprawiedliwości mają charakter arbitralny ${ }^{3}$.

My twierdzimy, że podstawą sprawiedliwości jest godność człowieka, na co wskazuje już tytuł opracowania. Sprawiedliwość znajduje swą realną, bytową podstawę w godności człowieka. Wyakcentujmy, ontyczną podstawą sprawiedliwości jest godność człowieka. Gdy zaś idzie o rozumienie sprawiedliwości, przyjmujemy tradycyjną formułę „oddać każdemu to, co mu się należy” (suum cuique tribuere $)^{4}$. Jest to ujęcie klasyczne, leżące u podstaw europejskiej refleksji nad sprawiedliwością i prawem.

II.

Pojęcie godności człowieka pojawiło się w filozofii starożytnej (np. u stoików). Niezależnie od tego godność człowieka, wiązana z jego szczególnym statusem wynikającym z aktu stworzenia, występuje w judaizmie ${ }^{5}$. Pojęcie godności znane było klasycznej myśli rzymskiej. Koncepcja godności człowieka była rozwijana $\mathrm{w}$ teologii i filozofii średniowiecznej wraz z koncepcją osoby jako wyjątkowego bytu; wielkość człowieka wiązano ze stworzeniem na obraz i podobieństwo Boga, wcieleniem i odkupieniem przez Chrystusa. Dla Tomasza z Akwinu - jak podaje Marek Piechowiak - „To nie bycie osobą jest ontyczną podstawą godności [...], ale to godność jest podstawą bycia osobą" ${ }^{\circ}$. Koncepcje godności rozwijało w czasach nowożytnych wielu myślicieli, chociażby Giovanni Pico della Mirandola, Hugo Grotius, Samuel Pufendorf?. Podstawę

2 Por. S. Wronkowska, Z. Ziembiński, Zarys teorii prawa, Poznań 1997, s. 95. Chaim Perelman (O sprawiedliwości, Warszawa 1959, s. 107) pisze: „Ze względu właśnie na charakter emocjonalny wartości leżących u podstaw każdego systemu normatywnego stosowanie sprawiedliwości w praktyce jest operacją, w której bierze także udział czynnik uczuciowy. Cały system sprawiedliwości może mieć pewne zabarwienie emocjonalne, nadane mu przez wartość podstawową, której on stanowi rozwinięcie racjonalne". Por. ibidem, s. 90.

3 Por. ibidem, s. 98, 108-109.

4 Formuła „sprawiedliwość polega na oddawaniu każdemu tego, co mu się należy” dobrze była znana Platonowi i Arystotelesowi. Por. np. Platon, Państwo, Kęty 2009, księga I, 332C, s. 19. Por. także: M. Piechowiak, Do Platona po naukę o prawach człowieka, [w:] Ksiega jubileuszowa profesora Tadeusza Jasudowicza, red. J. Białocerkiewicz, M. Balcerzak, A. Czeczko-Durlak, Toruń 2004, s. 339-345.

5 Szerzej: E. Soto Kloss, Starotestamentowe podstawy godności człowieka, [w:] Godność człowieka jako kategoria prawna, red. K. Complak, Wrocław 2001, s. 55-64.

6 M. Piechowiak, Filozofia praw człowieka. Prawa człowieka w świetle ich międzynarodowej ochrony, Lublin 1999, s. 273.

7 Zagadnienie godności było problemem ważkim, wielokrotnie podejmowanym. Popularny w okresie renesansu temat dignitas hominis jest uważany przez wielu historyków filozofii za symbol antropologii XV i XVI w. Jego echo dotarło do Polski, gdzie Jan z Trzciany (Joannes Arundinensis) w 1554 r. opublikował utwór pt. De natura ac dignitate hominis (zob. J. Czer- 
filozoficzną, jak się wydaje wiodącego europejskiego myślenia o godności, dał Immanuel Kant, według którego godność osoby jest wartością idealną, transcendentalną, absolutną (nierelatywną, bezwarunkową). W Uzasadnieniu metafizyki moralności napisał: „W państwie celów wszystko ma albo jakąś cenę, albo godność. To, co ma cenę, można zastąpić także przez coś innego, jako jego równoważnik, co zaś wszelką cenę przewyższa, a więc nie dopuszcza żadnego równoważnika, posiada godność"8. Kant podkreślił zatem niemożliwość zestawienia i porównania „godności” i „ceny”, jeśli nie chce się pogwałcić tej świętości, tj. godności osoby ludzkiej. Filozof ten zaakcentował „autonomię” jako „podstawę godności natury ludzkiej i każdej natury rozumnej”"

Pojęcie godności jest współcześnie rozwijane zwłaszcza w filozofii personalistycznej, dla której godność osoby ludzkiej (godność osobowa) jest centralną, rudymentarną kategorią.

III.

W rozważaniach o godności człowieka (dignitas hominis) oczywiście chodzi o godność przyrodzoną (wrodzoną), nieutracalną, niezniszczalną, a więc o godność osobową. Ta właśnie przyrodzona, niezbywalna, nienaruszalna godność człowieka jest podstawą sprawiedliwości. Rzecz jasna wyróżnia się także inne rodzaje godności: godność osobowościową, godność osobistą, godność społeczną ${ }^{10}$. Jednak tylko godność przyrodzona i niezbywalna stanowi podstawę sprawiedliwości i jest źródłem praw człowieka. Nazywa się ją godnością

kawski, Renesansowe koncepcje godności człowieka, [w:] Zagadnienie godności człowieka, red. J. Czerkawski, Lublin 1994, s. 64). Polski filozof zaapelował do człowieka, by poznał samego siebie, swoje możliwości i swoją godność, która ma swoje ostateczne racje w Bogu, a wewnątrzbytowo - w duszy i ciele człowieka. Jan z Trzciany wymienił osiem cech godności odnoszących się do ciała człowieka i trzynaście - do jego nieśmiertelnej duszy. Nobilitacja ciała w myśli Jana z Trzciany dokonuje się w odniesieniu do faktu wcielenia Syna Bożego, przyjmującego ciało człowieka, oraz do faktu zmartwychwstania, które jest dowodem na obecność uwielbionego ciała w osobie Jezusa Chrystusa jako prawdziwego Boga i prawdziwego Człowieka, powracającego ze swoim człowieczeństwem do wieczności niebiańskiej. Zob. T. Guz, O naturze wrodzonej godności człowieka, [w:] Normatywny wymiar godności człowieka, red. W. Lis, A. Balicki, Lublin 2012, s. 20-21. Por. J. Czerkawski, op. cit.

8 I. Kant, Uzasadnienie metafizyki moralności, Kęty 2013, s. 51. Por. szerzej: J. Potrzeszcz, Immanuela Kanta i Matthiasa Mahlmanna próba humanistycznego uzasadnienia godności człowieka, [w:] Abiit, non obiit. Księga poświęcona pamięci Księdza Profesora Antoniego Kościa SVD, red. A. Dębiński, P. Stanisz, T. Barankiewicz, J. Potrzeszcz, W.S. Staszewski, A. Szarek-Zwijacz, M. Wójcik, Lublin 2013, s. 273-299.

$9 \quad$ I. Kant, Uzasadnienie metafizyki..., s. 52.

10 Te konteksty godności były już rozpatrywane w filozofii starożytnej, a następnie w średniowieczu, nowożytności. Współcześnie analizowane są zwłaszcza w psychologii i socjologii. Są one jednak ważne także dla prawa i nauk prawnych. 
osobową, a niekiedy również godnością człowieka, godnością osoby, godnością osoby ludzkiej, godnością bytu ludzkiego ${ }^{11}$.

Współcześnie godność człowieka jest nie tylko kategorią filozoficzną, teologiczną, etyczną ${ }^{12}$, lecz także prawną ${ }^{13}$. Zasada ochrony przyrodzonej godności człowieka występuje w regulacjach międzynarodowych i krajowych.

Godność jest fundamentem praw człowieka, podstawą i źródłem praw człowieka i ich ochrony. Przyrodzona godność wskazuje na transcendencję człowieka wobec świata przyrody oraz świata techniki, ekonomii, ale też wobec społeczeństwa. Każdy człowiek istnieje jako osobny byt ${ }^{14}$. Jego istnienie jest rzeczywistością i z rzeczywistości wypływają wolności i prawa.

Godność jest pierwotna i niezależna od regulacji prawa pozytywnego, jest niezależna od woli prawodawcy, nie jest nadawana, nie może być odebrana żadnym działaniem ludzkim czy działaniem władz publicznych. Przymiotem godności jest jej nienaruszalność. Godność jest źródłem wszystkich praw, zarówno tych związanych z potrzebami materialnymi, jak i duchowymi i psychicznymi. Jest to obiektywne i niedysponowalne źródło wolności i praw człowieka. Z godności wypływają normy niezbywalne, niemodyfikowalne przez jakikolwiek ustrój czy prawodawstwo. Godność nie jest czymś dodanym do człowieka, ale wiąże się z samym faktem bycia człowiekiem ${ }^{15}$. Jest to wartość ontyczna, wpisana w strukturę bytu ludzkiego. Godność tkwi w samej strukturze bytowej człowieka (osoby ludzkiej).

Godność osobowa jest podstawą uznania każdego człowieka (osoby) za cel sam w sobie, a nigdy jako środek, z czym wiąże się zakaz instrumentalnego traktowania. Myśl o godności osoby ludzkiej znakomicie wyraził Kant w słynnym imperatywie: „Postępuj tak, byś człowieczeństwa tak w twej osobie, jako też w osobie każdego innego używał zawsze zarazem jako celu, nigdy tylko jako środka"16. Imperatyw ten wskazuje, że osoba w swym człowieczeństwie stanowi cel sam w sobie. Godność domaga się zatem nieprzedmiotowego traktowania

11 Por. F.J. Mazurek, Godność osoby ludzkiej podstawa praw człowieka, Lublin 2001, s. $19-20$.

12 Johannes Messner wskazał na cztery aspekty godności człowieka: teologiczny, metafizyczny, etyczny i ontologiczny. Szerzej: J. Messner, Was ist Menschenwürde?, „Internationale katholische Zeitschrift" 1977, Nr. 6, s. 239.

${ }_{13}$ Najogólniej wyróżnia się cztery koncepcje godności człowieka: teologiczne, filozoficzne, prawne, psychologiczno-socjologiczne.

${ }^{14}$ Zwróćmy uwagę na etymologię polskiego słowa „osoba”. Wskazuje ona, że jest to ktoś, kto istnieje w sposób jedyny i niepowtarzalny, czyli osobno. Por. T. Styczeń, Wprowadzenie do etyki, Warszawa 1993, s. 17-18. Aleksander Brückner (Stownik etymologiczny języka polskiego, Warszawa 1957, s. 384) wśród znaczeń słowa „osoba” podaje 'osobny', 'osobnie'.

15 Por. A. Bronk, Kategoria godności człowieka, „Annales UMCS. Sectio I” 2010, t. 35, s. 83.

16 I. Kant, Uzasadnienie metafizyki..., s. 46. Taką intuicję zdaje się wyrażać stara sentencja stoików: Homo homini res sacra. 
człowieka ${ }^{17}$. Wyklucza ona redukowanie człowieka do czegoś, co stanowi przedmiot wartościowania. Powtórzmy za Kantem, że godność jest bezcenna, przewyższa bowiem wszelką cenę. W Krytyce praktycznego rozumu filozof napisał:

Wynika teraz samo przez się, że w porządku celów człowiek (a wraz z nim każda rozumna istota) jest celem samym w sobie, tj. nie może być nigdy przez kogokolwiek (nawet przez Boga) traktowany jedynie jako środek, nie będąc zarazem sam przy tym celem, że więc człowieczeństwo w naszej osobie musi być dla nas samych święte; jest on bowiem podmiotem prawa moralnego $[\ldots]^{\prime \prime}$.

IV.

Godność człowieka (godność osobowa) współcześnie jest fundamentalną kategorią prawną. Trudno zaprzeczyć temu, iż treść polskiej regulacji konstytucyjnej dotyczącej godności człowieka jest przykładem wzorcowego rozwiązania. W Konstytucji Rzeczypospolitej Polskiej z dnia 2 kwietnia 1997 r. ${ }^{19}$ zasada przyrodzonej, niezbywalnej, nienaruszalnej godności człowieka, stanowiącej źródło wolności i praw człowieka i obywatela, jest wyrażona w art. 30²0, który brzmi: „Przyrodzona i niezbywalna godność człowieka stanowi źródło wolności i praw człowieka i obywatela. Jest ona nienaruszalna, a jej poszanowanie i ochrona jest obowiązkiem władz publicznych". Chodzi tu o godność osobową. Dobrem chronionym przez art. 30 Konstytucji RP jest właśnie godność osobowa człowieka

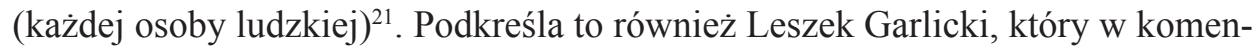
tarzu do Konstytucji RP wskazuje: „Art. 30 konstytucji odnosi się do osobowego ujęcia godności, traktuje ją więc jako immanentną cechę każdej istoty ludzkiej"22. Tatiana Chauvin podaje, że ,W dyskursie prawniczym [...] (na przykładzie pol-

17 Skoro człowiek jest celem samym w sobie, to nie może zostać podporządkowany kryterium użyteczności.

18 I. Kant, Krytyka praktycznego rozumu, Warszawa 1972, s. 211.

19 Dz.U. 1997, nr 78, poz. 483 z późn. zm.

${ }^{20}$ Chociaż dopiero art. 30 Konstytucji RP wyraża zasadę godności człowieka, to sama jego konstrukcja jest właściwa, można ją uznać za bardzo dobrą.

${ }^{21}$ Leszek Bosek (Gwarancje godności ludzkiej i ich wplyw na polskie prawo cywilne, Warszawa 2012, s. 81) trafnie zauważył: „Prace przygotowawcze, a przede wszystkim brzmienie Konstytucji RP, nie pozostawiają wątpliwości, że dobrem chronionym przez przepis art. 30 Konstytucji RP jest godność osobowa człowieka (każdej osoby ludzkiej)”. Autor ten zaakcentował również, że „pojęcie »godności osobowej człowieka« [...] w literaturze prawa konstytucyjnego chyba jednomyślnie uznaje się za przedmiot ochrony przepisu art. 30 Konstytucji RP [...]” (ibidem, s. 21). Również Krystian Complak (Godność człowieka, [w:] Konstytucja Rzeczypospolitej Polskiej. Komentarz encyklopedyczny, red. W. Skrzydło, S. Grabowska, R. Grabowski, Warszawa 2009, s. 165) podkreślił, że „Godność, o której mówi Konstytucja RP, jest tzw. godnością osobową”.

${ }^{22}$ L. Garlicki, Rozdziat II. Wolności, prawa i obowiązki człowieka i obywatela. Zasady ogólne. Artykut 30, [w:] Konstytucja Rzeczypospolitej Polskiej. Komentarz, red. L. Garlicki, t. 3, Warszawa 2003, s. 2. 
skiego prawa) [...] przyjmuje się więc w zasadzie bez dyskusji osobowe pojęcie godności jako cechy wrodzonej (wsobnej) każdej osoby ludzkiej"23. W literaturze akcentuje się, że Konstytucja RP odwołuje się do personalistycznej koncepcji godności osobowej człowieka ${ }^{24}$. Piotr Winczorek w komentarzu do art. 30 stwierdził:

Wolności i prawa znajdują uzasadnienie w samym człowieczeństwie i godności osoby ludzkiej (pojęcie „osoba ludzka” jest elementem filozoficznego słownika personalizmu, zwłaszcza w jego chrześcijańskiej wersji). Godności tej nikt nie może człowieka pozbawić, jest ona bowiem niezbywalna; nie można się jej też wyrzec ${ }^{25}$.

\section{Przytoczmy jeszcze wypowiedź L. Garlickiego:}

[...] punktem wyjścia i centralnym punktem odniesienia dla rozważań o konstytucyjnym pojęciu godności staje się ujmowanie tego pojęcia w chrześcijańskiej (katolickiej) nauce społecznej. Tylko zresztą przy takim założeniu możliwe jest nawiązanie do interpretacji pojęcia godności w tych europejskich porządkach konstytucyjnych, do których najbliżej jest sformułowaniom art. 30, a więc - przede wszystkim - w Niemczech i Hiszpanii ${ }^{26}$.

Bardzo ogólnie odnosząc się do art. 30 Konstytucji RP27, zaakcentujmy, że godność człowieka: jest przyrodzona i niezbywalna; stanowi źródło wolności i praw człowieka i obywatela; jest nienaruszalna, a obowiązkiem władz publicznych jest jej poszanowanie i ochrona. Żadna wolność ani żadne prawo nie mogą, jak wskazuje Andrzej Zoll, „sprzeciwiać się godności człowieka. [...] Żaden rodzaj wolności i żadne prawo nie mogą być chronione, jeżeli godzą w godność człowieka. Nie mogą bowiem pozostawać w sprzeczności do źródła, z którego się wywodzą"28.

Należy podkreślić, że godność człowieka jako kategoria konstytucyjna nawiązuje do rozwiązań przyjętych w Powszechnej Deklaracji Praw Człowieka uchwalonej przez Ogólne Zgromadzenie Narodów Zjednoczonych na posiedzeniu w Paryżu w dniu 10 grudnia 1948 r. $^{29}$, która artykułuje naturalne

${ }_{23}$ T. Chauvin, Homo iuridicus. Człowiek jako podmiot prawa publicznego, Warszawa 2014, s. 258.

24 Zob. np. L. Bosek, op. cit., s. 397.

25 P. Winczorek, Komentarz do Konstytucji Rzeczypospolitej Polskiej z dnia 2 kwietnia 1997 roku, Warszawa 2008, s. 79.

26 L. Garlicki, op. cit., s. 7.

27 Szerzej: W. Dziedziak, O prawie stusznym (perspektywa systemu prawa stanowionego), Lublin 2015, s. 100-105.

28 A. Zoll, Godność człowieka jako źródło wolności i praw, [w:] Hominum causa omne ius constitutum est. Księga jubileuszowa ku czci Profesor Alicji Grześkowiak, red. A. Dębiński, M. Gałązka, R.G. Hałas, K. Wiak, Lublin 2006, s. 281.

29 Na forum Organizacji Narodów Zjednoczonych personalista Jacques Maritain postawił w centrum dyskusji godność każdej osoby ludzkiej i przyczynił się do uznania tej kategorii za podstawę międzynarodowego systemu ochrony praw człowieka. O wpływie filozofii personalistycznej Maritaina na Powszechną Deklarację Praw Człowieka por. F.J. Mazurek, Godność osoby ludzkiej..., s. 128-130. 
prawa $^{30}$. Deklaracja była pomyślana jako „wspólny standard dla wszystkich ludzi i narodów".

Preambuła Deklaracji zaczyna się następująco: „Zważywszy, że uznanie przyrodzonej godności oraz równych i niezbywalnych praw wszystkich członków wspólnoty ludzkiej jest podstawą wolności, sprawiedliwości i pokoju na świecie [...]”, a art. 1 głosi: „Wszystkie istoty ludzkie rodzą się wolne i równe w godności i prawach ${ }^{31}$. Są one obdarzone rozumem i sumieniem oraz powinny postępować w stosunku do siebie wzajemnie w duchu braterstwa" ${ }^{32}$. Trzeba też zaakcentować, że Deklaracja w Preambule głosi, iż tak pojęte prawa człowieka powinny być „chronione przez przepisy prawa”. Preambuła również w dalszej części odwołuje się do godności: „,...] zważywszy, że ludy Narodów Zjednoczonych potwierdziły w Karcie swą wiarę w podstawowe prawa człowieka, w godność i wartość osoby ludzkiej”.

Podkreślmy, iż Preambuła PDPCz wskazuje na przyrodzony charakter godności i stwierdza, że jest ona podstawą sprawiedliwości.

Także w Międzynarodowych Paktach Praw Człowieka z 16 grudnia 1966 r. przyjęto, że prawa człowieka wywodzą się z przyrodzonej godności osoby ludzkiej. Chodzi tu o sformułowania zawarte w obu Wstępach, w których uznaje się, że „prawa te wywodzą się z przyrodzonej godności osoby ludzkiej” (these rights derive from the inherent dignity of the human person $)^{33}$.

Zacytujmy też fragment Preambuły Konwencji o Prawach Dziecka: ,[...] zgodnie z zasadami zawartymi w Karcie Narodów Zjednoczonych uznanie wrodzonej godności oraz równych i niezbywalnych praw wszystkich członków rodziny ludzkiej jest podstawą wolności, sprawiedliwości oraz pokoju na świecie [...”’34.

30 Deklaracja została przyjęta 48 głosami - znamienne jest, że byłe państwa komunistyczne, w tym Polska, wstrzymały się od głosu. Sama nazwa dokumentu: Deklaracja - wskazuje na to, że prawa w niej wyrażone istnieją realnie, a jej treść ma charakter deklaratoryjny, a nie konstytutywny. Deklaracja nie ustanawia, nie tworzy praw człowieka, lecz jedynie potwierdza, właśnie tylko deklaruje.

31 Jak trafnie zauważył Wojciech Bołoz, określenie ,rodzą się wolne i równe w godności i prawach", nie oznacza, iż warunkiem posiadania godności jako podstawy równości i wolności jest fakt urodzenia. Por. W. Bołoz, Bioetyka i prawa człowieka, Warszawa 2007, s. 33.

32 Deklaracja wyraźnie nawiązuje do tradycji prawa naturalnego, jest przykładem wyartykułowania tego prawa. Por. K. Motyka, Prawa człowieka. Wprowadzenie. Wybór źródet, Lublin 2001, s. 32-33. Jerzy Stelmach zauważa: „Deklaracja Powszechna Praw Człowieka w zasadzie odwoływała się do klasycznej (neotomistycznej) konstrukcji prawa natury" - J. Stelmach, R. Sarkowicz, Filozofia prawa XIX i XX wieku, Kraków 1998, s. 65. Z kolei Hanna Waśkiewicz wskazuje, że Deklaracja „opiera się na prawie naturalnym i obowiązuje mocą prawa naturalnego” - H. Waśkiewicz, Prawo naturalne - prawo czy norma moralna, „Roczniki Filozoficzne” 1970, z. 2, s. 15.

33 Por. Wstęp do Międzynarodowego Paktu Praw Gospodarczych, Społecznych i Kulturalnych (Dz.U. 1977, nr 38, poz. 169) oraz Wstęp do Międzynarodowego Paktu Praw Obywatelskich i Politycznych (Dz.U. 1977, nr 38, poz. 167).

34 Konwencja o Prawach Dziecka przyjęta przez Zgromadzenie Ogólne Narodów Zjednoczonych dnia 20 listopada 1989 r. (Dz.U. 1991, nr 120, poz. 526 z późn. zm.). 
Trzeba dodać, że do godności odwołuje się wiele innych aktów, deklaracji i rezolucji międzynarodowych oraz orzecznictwo sądów konstytucyjnych wielu państw. Pojęcie to występuje także w konstytucjach niektórych państw ${ }^{35}$.

Do zasady godności człowieka wielokrotnie nawiązywał polski Trybunał Konstytucyjny, akcentując między innymi, że jest to „wartość transcendentna, pierwotna wobec innych praw i wolności człowieka (dla których jest źródłem), przyrodzona i niezbywalna [...]"36 oraz stanowi „fundament całego porządku prawnego w państwie" ${ }^{37}$. Podkreślany był również bezwzględny zakaz jej naruszania $^{38}$ oraz że ,jest to jedyne prawo, wobec którego nie byłoby możliwe zastosowanie zasady proporcjonalności" ${ }^{39}$.

Godność osobowa jest jednakowa dla wszystkich ludzi i stanowi podstawę dla innych rodzajów godności (osobowościowej, osobistej, społecznej), które można nabyć, niejako wypracować. Niestety, niekiedy godność osobowa jest mylona z godnością osobowościową. A przecież tylko godność osobowa jest przyrodzona (wrodzona), natomiast godność osobowościowa jest nabywana ${ }^{40}$. Godność osoby czy osobowa jak podkreśla Franciszek J. Mazurek - jest podstawą etyki uniwersalnej, a godność osobowościowa (bez odwoływania się do godności osobowej) - etyki relatywnej ${ }^{41}$.

Podsumowując tok dotychczasowych rozważań, podkreślmy, że godność nie jest kreowana aktem ludzkiej władzy, jest bowiem rzeczywistością zastaną i - jak można powiedzieć - zadaną człowiekowi. Godność osobowa jest nienabywalna, ponieważ wiąże się z samą istotą człowieka. Nie można oddzielić godności od bytu ludzkiego, od tego, co istnieje. Wyraźnie trzeba zaakcentować, że godność jest od człowieka nieodłączna, niezależna od kontekstu społecznego czy historycznego. Nie zależy od statusu społecznego czy majątkowego, stanu umysłowego, poziomu moralnego, wieku, płci, poglądów politycznych, wykształcenia itp. - jest przyrodzona (wrodzona) i od człowieka niezależna. Nie może on jej zniweczyć ani unicestwić.

Konkludując, godność jest wrodzona, niezbywalna, nieutracalna. Jest wartością bezwzględną, niestopniowalną, niederogowalną, bezwarunkową. Godność

35 Na przykład art. 1 ust. 1 Ustawy Zasadniczej Republiki Federalnej Niemiec z 1949 r., art. 1 Konstytucji Portugalii z 1976 r., art. 10 Konstytucji Hiszpanii z 1978 r., art. 7 Konstytucji Szwajcarii z $1999 \mathrm{r}$.

36 Wyrok TK z dnia 5 marca 2003 r., K 7/01, OTK ZU 2003, Seria A, nr 3, poz. 19. W wyroku tym Trybunał Konstytucyjny m.in. zaakcentował, że godność „towarzyszy człowiekowi zawsze i nie może być naruszona ani przez prawodawcę, ani przez określone czyny innych podmiotów. [...] Godność człowieka podlega ochronie bezwzględnej”.

37 Wyrok TK z dnia 4 kwietnia 2001 r., K 11/00, OTK ZU 2001, nr 3, poz. 54.

38 Ibidem.

39 Wyrok TK z dnia 5 marca 2003 r., K 7/01, OTK ZU 2003, Seria A, nr 3, poz. 19.

40 Szerzej: F.J. Mazurek, Godność osoby ludzkiej..., s. 75-76.

${ }^{41}$ Por. ibidem, s. 80-81. Por. także: idem, Pojęcie godności czlowieka. Historia i miejsce w projektach Konstytucji III Rzeczypospolitej, „Roczniki Nauk Prawnych” 1996, t. 6, s. 23. 
jest wpisana w istotę człowieczeństwa, tkwi w ontycznej strukturze bytu ludzkiego. Jest wartością ontyczną, trwałą, zobowiązującą (także innych do jej respektowania). To wartość obiektywna, stała i absolutna. Jest niezniszczalna. Jest równa - to równa godność.

Właśnie tak rozumiana godność stanowi podstawę sprawiedliwości i jej wymogów nakazujących oddać „każdemu, co jest jego”, co jest własne, co jest należne. Przypomnijmy, że kategoria godności jest również rzeczywistością prawną.

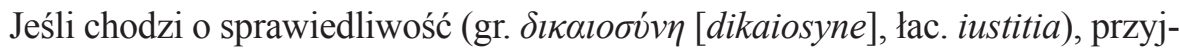
mujemy - jak już wspomniano - klasyczne rozumienie. Chodzi o to, by „oddać każdemu to, co mu się należy" (suum cuique tribuere). Powszechnie znana jest zwięzła definicja sformułowana przez Ulpiana: Iustitia est constans et perpetua voluntas ius suum cuique tribuendi ${ }^{42}$. Tutaj trzeba jednak dodać, i w pewnym sensie doprecyzować, że wola ma być, powinna być inspirowana i kierowana rozumem ${ }^{43}$.

Sprawiedliwość domaga się, by „każdemu oddać, co jest jego”. Suum cuique - oddać „każdemu, co jest jego”. A co oddać, co jest jego? Co jest swoje, co jest własne, co jest należne? Tu chodzi o uprawnienia człowieka. Człowiek ma uprawnienia, ma prawa wypływające z przyrodzonej godności. Wypływają one ze struktury bytowej człowieka. Są to uprawnienia naturalne. Formułę „oddać każdemu to, co się komu należy", wiążemy z naturalnym uprawnieniem, prawem podmiotowym, prawem do czegoś, a zatem oddać „coś, do czego ma się prawo”.

Sprawiedliwość jest respektowaniem należnych człowiekowi uprawnień. Ich źródłem, potwórzmy, jest przyrodzona godność człowieka - są to więc uprawnienia, prawa naturalne ${ }^{44}$. Te naturalne uprawnienia/prawa muszą być zapewnione, zagwarantowane, realizowane przez prawo stanowione. Istnienie tych uprawnień zobowiązuje władzę prawodawczą (osoby ją piastujące) do ich zabezpieczenia, urealnienia. Wymieńmy najbardziej fundamentalne: prawo każdego człowieka do życia oraz prawo do osobowego rozwoju.

Zagwarantowanie tych praw nie jest kwestią jakiejś konwencji, uzgodnień, umowy czy gier politycznych, lecz kwestią sprawiedliwości - naturalnej sprawiedliwości, bo tak ją trzeba nazwać.

Prawo do rozwoju, prawo do integralnego rozwoju człowieka dotyczy rozwoju fizycznego, intelektualnego, moralnego. Prawo będące wyrazem sprawiedli-

${ }^{42}$ D. Ulpianus, D. 1,1,10 pr.

43 Chodzi o to, by wola nie szła przed rozumem. Wola bez rozumu może być nieroztropna, nierozsądna, może być ślepa.

${ }^{44}$ Chodzi o rzeczywiste naturalne prawa, nie zaś o uprawnienia będące wynikiem (rezultatem) jakichś ideologicznych nacisków. Pojawia się bowiem groźba uznania za uprawnienia czy prawa człowieka jakichś uprawnień pozornych. 
wości nie może przeszkadzać w rozwoju człowieka, np. w rozwoju poznawczym - chodzi tu o prawo do prawdy, niestety niekiedy deptane, łamane. Prawo respektujące wymogi naturalnej sprawiedliwości nie może przecież być przyczyną ograniczeń i deformacji rozwoju człowieka.

Rozwój osobowy człowieka to kategoria, która nie jest wyrazem jakiegoś partykularnego myślenia, właściwego dla pewnych nurtów filozofii, to nie jest jakaś abstrakcja. Mówią o tym regulacje normatywne z Powszechną Deklaracją Praw Człowieka na czele. Można tu wspomnieć o: art. 25 PDPCz, w którym stwierdza się, że „Każdy człowiek ma prawo do poziomu życia zapewniającego zdrowie i dobrobyt jemu i jego rodzinie [...]"; art. 26 PDPCz, w którym mowa jest o tym, że „Każdy człowiek ma prawo do oświaty. [...] Celem oświaty będzie pełny rozwój osobowości ludzkiej [...]”; art. 23 PDPCz, który brzmi: „Każdy człowiek ma prawo do pracy $[. .$.$] . Każdy pracujący ma prawo do odpowiedniego zadowalającego wyna-$ grodzenia, zapewniającego jemu i jego rodzinie egzystencję odpowiadającą godności ludzkiej [...]". W tej materii istotne są art. 6 i 7 Międzynarodowego Paktu Praw Gospodarczych, Społecznych i Kulturalnych, zgodnie z którymi Państwa-Strony uznają: „prawo do pracy”, ,prawo każdego do korzystania ze sprawiedliwych i korzystnych warunków pracy, obejmujących w szczególności [...] zadowalające warunki życia dla nich samych i ich rodzin [...]". W art. 13 tego Paktu stanowi się, że „nauczanie powinno zmierzać do pełnego rozwoju osobowości i poczucia godności ludzkiej i umacniać poszanowanie praw człowieka i podstawowych wolności”. Z kolei art. 29 Konwencji o Prawach Dziecka głosi, że „Państwa-Strony są zgodne, że nauka dziecka będzie ukierunkowana na rozwijanie w jak najpełniejszym zakresie osobowości, talentów oraz zdolności umysłowych i fizycznych dziecka”. Już te artykuły wskazują, jak istotny jest pełen rozwój człowieka.

Oczywiście, by móc się rozwijać, trzeba być/istnieć. Tutaj dodajmy, że punktem wyjścia jest prawo do życia, prawo do narodzenia. Prawo do życia od chwili poczęcia jest syntezą wszystkich praw, bez niego wszelkie inne tracą sens.

Sprawiedliwość wymaga zapewnienia warunków sprzyjających rozwojowi człowieka oraz godnego bytowania w społeczeństwie. Chodzi o warunki prowadzące do uzyskania przez człowieka pełni istnienia i życia. Regulacje prawne mają powoływać struktury czy instytucje, których celem jest zapewnienie możliwości wszechstronnego rozwoju. Sprawiedliwe prawo, poprzez odpowiednie regulacje, powinno wspierać człowieka w jego rozwoju.

Jest oczywiste, że sprawiedliwość, o której mówimy, mająca podstawę w godności człowieka, nie pomija tych, którzy nie mogą przyczyniać się, nie mogą mieć wkładu w rozwój wspólnoty. Osoby te należy objąć odpowiednią pomocą i opieką. Sprawiedliwość wymaga, by każdemu człowiekowi zapewnić egzystencję odpowiadającą godności osoby ludzkiej. Można by powiedzieć, że chodzi o zaspokojenie potrzeb podstawowych, zasadniczych. Nie chodzi tu o subiektywnie odczuwane potrzeby, o ich relatywność, lecz o elementarne, zobiektywizowane 
potrzeby, takie jak: żywność, odzież, mieszkanie, opieka zdrowotna ${ }^{45}$. Wyraźnie podkreślmy, że sprawiedliwość dotyczy praw przynależnych każdemu człowiekowi, a więc także niepełnosprawnym, chorym, bezrobotnym, odrzuconym przez bliskich. Sprawiedliwość dotyczy każdego i nikt nie może zostać pominięty.

\section{$* * *$}

W podsumowaniu zaakcentujmy, że sprawiedliwości nie rozumiemy w kategoriach konwencji, nie jest (nie może być) ona konwencją społeczno-pragmatyczną, konstruktem umownym, efektem/rezultatem umowy społecznej (hipotetycznej umowy), nie opieramy jej na przeżyciach, uczuciach, emocjach ani na subiektywnych preferencjach i zmiennych ludzkich opiniach, nie przyjmujemy twierdzenia o arbitralnym charakterze jej podstaw. W naszym ujęciu jest ona oparta na głębszych i bardziej pewnych podstawach oraz na mocnym fundamencie.

W konkluzji należy stwierdzić, że podstawą sprawiedliwości jest rzeczywistość obiektywna niezależna od konwencji, umowy, uczuć czy woli prawodawcy. Sprawiedliwość znajduje swą realną, bytową podstawę w przyrodzonej godności człowieka, a jest to równa godność. Sprawiedliwość jest ugruntowana w rzeczywistości, jaką jest człowiek - byt sam w sobie i dla siebie. Zawsze cel, nigdy tylko środek.

Co ważne, rozważania dotyczyły sprawiedliwości, którą zwiemy sprawiedliwością naturalną. Jej realizacja jest obowiązkiem władzy (zawiadujących życiem społecznym). Jeśli jej wymogi nie są realizowane, to nie jest to argument przeciwko sprawiedliwości. Dodać też trzeba, że inną kwestią (wymagającą odrębnych analiz) jest związek godności ${ }^{46}$ z regułami i zasadami sprawiedliwości rozdzielczej, a także sprawiedliwości wyrównawczej.

\section{BIBLIOGRAFIA}

Bołoz W., Bioetyka i prawa człowieka, Warszawa 2007.

Bosek L., Gwarancje godności ludzkiej i ich wpływ na polskie prawo cywilne, Warszawa 2012.

Bronk A., Kategoria godności człowieka, „Annales UMCS. Sectio I” 2010, t. 35.

Brückner A., Stownik etymologiczny języka polskiego, Warszawa 1957.

Chauvin T., Homo iuridicus. Człowiek jako podmiot prawa publicznego, Warszawa 2014.

Complak K., Godność człowieka, [w:] Konstytucja Rzeczypospolitej Polskiej. Komentarz encyklopedyczny, red. W. Skrzydło, S. Grabowska, R. Grabowski, Warszawa 2009. życia.

${ }^{45}$ Człowiek ma uprawnienie, ma prawo do otrzymania środków koniecznych dla godziwego

46 Chodzi tu także o godność osobowościową, nabytą, wypracowaną, zależną od wolnych decyzji człowieka. Godność osobowościowa wiąże się z obszarem zachowań/działań człowieka. Godność ta, związana z osobowością człowieka, nie jest równa, można ją posiadać w rożnym stopniu i jest utracalna. Istotna jest również godność społeczna związana z pełnionym przez człowieka urzędem, stanowiskiem bądź funkcją społeczną. 
Czerkawski J., Renesansowe koncepcje godności człowieka, [w:] Zagadnienie godności człowieka, red. J. Czerkawski, Lublin 1994.

Dworkin R., Biorac prawa poważnie, Warszawa 1998.

Dziedziak W., O prawie stusznym (perspektywa systemu prawa stanowionego), Lublin 2015.

Garlicki L., Rozdział II. Wolności, prawa i obowiązi człowieka i obywatela. Zasady ogólne. Artykut 30, [w:] Konstytucja Rzeczypospolitej Polskiej. Komentarz, red. L. Garlicki, t. 3, Warszawa 2003.

Guz T., O naturze wrodzonej godności człowieka, [w:] Normatywny wymiar godności człowieka, red. W. Lis, A. Balicki, Lublin 2012.

Kant I., Krytyka praktycznego rozumu, Warszawa 1972.

Kant I., Uzasadnienie metafizyki moralności, Kęty 2013.

Konstytucja Hiszpanii z 1978 r.

Konstytucja Portugalii z 1976 r.

Konstytucja Rzeczypospolitej Polskiej z dnia 2 kwietnia 1997 r. (Dz.U. 1997, nr 78, poz. 483 z późn. zm.).

Konstytucja Szwajcarii z 1999 r.

Konwencja o Prawach Dziecka przyjęta przez Zgromadzenie Ogólne Narodów Zjednoczonych dnia 20 listopada 1989 r. (Dz.U. 1991, nr 120, poz. 526 z późn. zm.).

Mazurek F.J., Godność osoby ludzkiej podstawa praw człowieka, Lublin 2001.

Mazurek F.J., Pojęcie godności człowieka. Historia i miejsce w projektach Konstytucji III Rzeczypospolitej, „Roczniki Nauk Prawnych” 1996, t. 6.

Messner J., Was ist Menschenwürde?, „Internationale katholische Zeitschrift“ 1977, Nr. 6.

Międzynarodowy Pakt Praw Gospodarczych, Społecznych i Kulturalnych otwarty do podpisu w Nowym Jorku dnia 19 grudnia 1966 r. (Dz.U. 1977, nr 38, poz. 169).

Międzynarodowy Pakt Praw Obywatelskich i Politycznych otwarty do podpisu w Nowym Jorku dnia 19 grudnia 1966 r. (Dz.U. 1977, nr 38, poz. 167).

Motyka K., Prawa człowieka. Wprowadzenie. Wybór źródet, Lublin 2001.

Perelman Ch., O sprawiedliwości, Warszawa 1959.

Piechowiak M., Do Platona po nauke o prawach człowieka, [w:] Księga jubileuszowa profesora Tadeusza Jasudowicza, red. J. Białocerkiewicz, M. Balcerzak, A. Czeczko-Durlak, Torun 2004.

Piechowiak M., Filozofia praw człowieka. Prawa człowieka w świetle ich międzynarodowej ochrony, Lublin 1999.

Platon, Państwo, Kęty 2009.

Potrzeszcz J., Immanuela Kanta i Matthiasa Mahlmanna próba humanistycznego uzasadnienia godności człowieka, [w:] Abiit, non obiit. Księga poświęcona pamięci Księdza Profesora Antoniego Kościa SVD, red. A. Dębiński, P. Stanisz, T. Barankiewicz, J. Potrzeszcz, W.S. Staszewski, A. Szarek-Zwijacz, M. Wójcik, Lublin 2013.

Powszechna Deklaracja Praw Człowieka uchwalona 10 grudnia 1948 r. w Paryżu przez Ogólne Zgromadzenie Organizacji Narodów Zjednoczonych.

Rawls J., Teoria sprawiedliwości, Warszawa 1994.

Soto Kloss E., Starotestamentowe podstawy godności człowieka, [w:] Godność człowieka jako kategoria prawna, red. K. Complak, Wrocław 2001.

Stelmach J., Sarkowicz R., Filozofia prawa XIX i XX wieku, Kraków 1998.

Styczeń T., Wprowadzenie do etyki, Warszawa 1993.

Ustawa Zasadnicza Republiki Federalnej Niemiec z 1949 r.

Waśkiewicz H., Prawo naturalne - prawo czy norma moralna, „Roczniki Filozoficzne” 1970, nr 2.

Winczorek P., Komentarz do Konstytucji Rzeczypospolitej Polskiej z dnia 2 kwietnia 1997 roku, Warszawa 2008.

Wronkowska S., Ziembiński Z., Zarys teorii prawa, Poznań 1997.

Wyrok TK z dnia 4 kwietnia 2001 r., K 11/00, OTK ZU 2001, nr 3, poz. 54. 
Wyrok TK z dnia 5 marca 2003 r., K 7/01, OTK ZU 2003, Seria A, nr 3, poz. 19.

Zoll A., Godność człowieka jako źródło wolności i praw, [w:] Hominum causa omne ius constitutum est. Księga jubileuszowa ku czci Profesor Alicji Grześkowiak, red. A. Dębiński, M. Gałązka, R.G. Hałas, K. Wiak, Lublin 2006.

\section{SUMMARY}

The article discusses the issue of the fundamentals of justice. Despite the dominant narratives about the conventional nature of this category, it is claimed that the fundamental of justice is the inherent human dignity. Justice finds its his real and substantial foundation in the dignity of the human person. Therefore, the inherent (innate), non-transferable, inalienable dignity, which is associated with the essence of man, is the foundation of justice and its requirements requiring to "give to each what he deserves" (suum cuique tribuere), to give "to each his own" or his due, which means the natural human rights, the most rudimentary of which is the right to life and the right to personal development. The assertion of those basic human rights is not a matter of any convention, agreements, contracts or the will of the legislator, or any political games, but a matter of justice, natural justice.

Keywords: justice; human dignity; natural justice

\section{STRESZCZENIE}

W artykule podjęto zagadnienie podstaw sprawiedliwości. Pomimo dominujących narracji o konwencjonalnym charakterze tej kategorii przyjęto, że podstawą sprawiedliwości jest przyrodzona godność człowieka. Sprawiedliwość znajduje swą realną, bytową podstawę w godności człowieka. Tak zatem wiążąca się z samą istotą człowieka przyrodzona (wrodzona), niezbywalna, nieutracalna godność jest podstawą sprawiedliwości i jej wymogów nakazujących „oddać każdemu to, co mu się należy” (suum cuique tribuere), oddać „każdemu, co jest jego”, co jest własne, co jest należne. A chodzi o naturalne uprawnienia, prawa człowieka, z których najbardziej elementarne to prawo do życia i prawo do osobowego rozwoju. Zagwarantowanie/urealnienie tych uprawnień, podstawowych praw człowieka, nie jest kwestią jakiejś konwencji, uzgodnień, umowy, woli prawodawcy czy gier politycznych, lecz kwestią sprawiedliwości - naturalnej sprawiedliwości.

Słowa kluczowe: sprawiedliwość; godność człowieka; sprawiedliwość naturalna 